\title{
Innovative directions of development of ceramic materials for dentistry
}

\author{
O.V. Savvova (ORCID 0000-0001-6664-2274), G.K. Voronov (ORCID 0000-0003-1205-8608), \\ O.I. Fesenko (ORCID 0000-0003-3888-9493), Yu.O. Smirnova (ORCID 0000-0001-6664-2274), \\ E. Bairamov
}

O.M. Beketov National University of Urban Economy in Kharkiv, str. Marshala Bazhanova, 17, Kharkiv, 61002, Ukraine

Tel.: +380577073174, +380500201628

E-mail:savvova_oksana@ukr.net,Hennadii.Voronov@kname.edu.ua,Oleksii.Fesenko@kname.edu.ua, Yuliia.Smyrnova@kname.edu.ua,Emin.Bairamov@kname.edu.ua

Article info: received 03.03.2021, revised 12.03.2021, accepted 24.03.2021

Savvova, O.V., Voronov, G.K., Fesenko, O.I., Smirnova, Yu.O., Bairamov, E. (2021) Innovative directions of development of ceramic materials for dentistry 1(50), DOI: 10.26909/csl.1.2021.3

The need to improve the level of dental health of the population of Ukraine was identified. The prospects for the use of ceramic prostheses to provide quality medical care in dentistry have been established. An analytical review of various types of ceramic and glass-ceramic materials used as dental prostheses for tooth replacement: porcelain, alumina, zirconium oxide, glass-ceramics based on leucite and lithium disilicate and mica with the addition of fluorides. Peculiarities of the structure and operational properties of ceramic and glass-ceramic materials for dentistry have been identified, their advantages and disadvantages have been established. The effectiveness of the use of glass-ceramic materials based on lithium disilicate for dental prosthetics is substantiated. The basic lithium silicate system was selected and glasses for obtaining glass-ceramic crowns based on lithium disilicate by the method of high-temperature pressing and calcium phosphate-silicate system for obtaining glass-ceramic coatings were synthesized.

The methodological approach to the development of glass-ceramic prostheses based on lithium disilicate is determined. The limits of the compositions of oxide components are determined and raw materials for the synthesis of the glass matrix are selected. The technological parameters of melting $\left(\mathrm{T}=1350-1400{ }^{\circ} \mathrm{C}\right)$ and heat treatment with simultaneous formation of products (stage of nucleation $\mathrm{T}=600-650^{\circ} \mathrm{C}, \tau=30-60 \mathrm{~min}$; stages of formation $\mathrm{T}=900{ }^{\circ} \mathrm{C}$, $\tau \approx 20 \mathrm{~min}$ ) are selected. The composition of fluoroapatite glass-ceramic coating for glazing of glass-ceramics and the mode of its firing $\left(\mathrm{T}=800-850^{\circ} \mathrm{C}, \tau \approx 1,0-1,5 \mathrm{~min}\right)$ were determined. The serviceability of the developed glass-ceramic samples DL st. glass, which were obtained by the technology of high-temperature pressing, are determined.

The comparative analysis of glass-ceramic prostheses for dentistry allowed to establish that the operational properties of the developed glass-ceramic prostheses according to ISO 6872:2015 are at the level of world analogues. This will allow them to successfully compete in the Ukrainian market with well-known foreign counterparts and help ensure the social priorities of the state in the field of health care.

Key words: glass-ceramic materials, lithium disilicate, ceramic prostheses, dentistry.

\section{Інноваційні напрямки розроблення керамічних матеріалів для стоматології}

\author{
О.В. Саввова, Г.К. Воронов, О.І. Фесенко, Ю.О. Смирнова, Е. Байрамов
}

Харківський національний університет міського господарства ім. О.М. Бекетова, Харків, Украӥна

Визначено необхідність підвищення рівня стоматологічного здоров'я населення України. Встановлено перспективність застосування керамічних протезів для забезпечення якісного медичного обслуговування в стоматології. Проведено аналітичний огляд різних видів керамічних та склокерамічних матеріалів, які застосовуються 
як стоматологічні протези для заміни зубів: порцеляна, оксид алюмінію, оксид цирконію, склокераміка на основі лейциту та дисилікату літію й слюди з добавкою фторидів. Визначено особливості структури та експлуатаційних властивостей керамічних та склокерамічних матеріалів для стоматології, встановлено їх переваги та недоліки. Обгрунтовано ефективність застосування склокерамічних матеріалів на основі дисилікату літію для протезування зубів. Обрано базову літійсилікатну систему та синтезовано стекла для одержання склокерамічних коронок на основі дисилікату літію методом високотемпературного пресування та кальційфосфатосилікатну систему для одержання склокристалічних покриттів.

Визначено методологічний підхід розробки склокерамічних протезів на основі дисилікату літію. Визначено межі складів оксидних компонентів та обрано сировинні матеріали для синтезу скломатриці. Обрано технологічні параметри варки ( $\left.\mathrm{T}=1350-1400{ }^{\circ} \mathrm{C}\right)$ та термічної обробки 3 одночасним формуванням виробів (стадія зародкоутворення $\mathrm{T}=600-650{ }^{\circ} \mathrm{C}, \tau=30-60$ хв.; стадії формування $\mathrm{T}=900{ }^{\circ} \mathrm{C}, \tau \approx 20$ хв). Визначено склад фторапатитового склокерамічного покриття для глазурування склокераміки та режим його випалу ( $\mathrm{T}=800-850{ }^{\circ} \mathrm{C}, \tau \approx 1,0-1,5$ хв.). Визначено експлуатаційні властивості розроблених склокерамічних зразків DL st.glass, які отримано за технологією високотемпературного пресування.

Проведений порівняльний аналіз склокерамічних протезів для стоматології дозволив встановити, що експлуатаційні властивості розроблених склокерамічних протезів за ISO 6872:2015 знаходяться на рівні світових аналогів. Це дозволить їм успішно конкурувати на ринку України з відомим зарубіжними аналогами та сприяти забезпеченню соціальних пріоритетів держави у напрямку охорони здоров'я.

\section{Вступ}

Важливою глобальною медико-соціальною проблемою сучасності є стрімке старіння населення. Навіть у країнах 3 високим рівнем соціальної захищеності в осіб різної вікової категорії виявлена значна поширеність та інтенсивність основних стоматологічних захворювань, що призводить до втрати зубів. Не менш важливою проблемою є дефектність зубів у дітей та їх втрата у працездатного населення, що пов'язана 3 техногенним навантаженням, стихійними лихами та катастрофами, бойовими діями та ін. 3 урахуванням «Стратегії сталого розвитку України до 2030 року», що орієнтована насамперед на людину, а також поліпшення якості iї життя у сприятливому соціально-економічному середовищі та екологічно чистому, здоровому, різноманітному природному довкіллі, необхідною умовою іiі виконання є забезпечення охорони здоров'я нації. Саме підвищення рівня стоматологічного здоров'я населення України $є$ важливою складовою медичного обслуговування, що дозволить забезпечити конкурентоспроможність країни у майбутньому.

На сьогоднішній день розробки в області зубопротезування спрямовані на створення нових видів керамічних протезів, зокрема, таких що характеризуються нетоксичністю, високими естетичними властивостями та тотожністю механічних і біологічних властивостей до відповідних властивостей природних зубів [1]. Наразі на ринку стоматологічних матеріалів представлена значна кількість керамічних мас і сплавів для виготовлення керамічних протезів різних фірм-виробників. Особливу увагу із закордонних фірм-виробників заслуговують матеріали фірм Ivoclar Vivadent: IPS Empress; EstheticIPS; EmpressIPS e.max Ceram; Harmony; d.SIGN; Callisto
Implant; Callisto Implant; Callisto Pd; Brite Gold XH; d.SIGN [2]. Високий інтерес та перспективність розробки вітчизняних стоматологічних матеріалів для виготовлення керамічних протезів підтверджується наявністю Українських металевих дентальних імплантатів фірм Bauer's Implants та Vitaplant [3], що характеризуються високими експлуатаційними властивостями, подібних до світових аналогів, але мають нижчу вартість. Однак розробці та впровадженню вітчизняних керамічних зубних протезів приділяється замало уваги, зважаючи на стрімкий розвиток біоматеріалознавства в Україні. Створення нових типів керамічних протезів стоматологічного призначення дозволить значно підвищити конкурентоспроможність вітчизняних імплантатів та ефективність зубопротезування.

Наведемо аналіз існуючих керамічних протезів стоматологічного призначення.

1. Стоматологічна пориеляна.

Протягом тривалого часу практично єдиним керамічним матеріалом, що використовувався в медицині, була порцеляна [4], що має високі косметологічні характеристики.

За своїм призначенням порцелянові маси $є$ вихідним матеріалом для:

- створення стандартних порцелянових коронок та заготовок для порцелянових вкладок;

- створення індивідуальних порцелянових коронок та вкладок в умовах зубопротезної лабораторії;

- облицювання суцільнолитих каркасів металевих незнімних зубних протезів (коронок, мостів).

Сучасна стоматологічна порцеляна є результатом удосконалення побутової декоративної порцеляни. Стоматологічну порцеляну синтезують на основі 
польового шпату в системі $\mathrm{K}_{2} \mathrm{O}-\mathrm{Al}_{2} \mathrm{O}_{3}-\mathrm{SiO}_{2}$. $\mathrm{У}$ таблиці 1 для порівняння наведені компонентні склади побутової та стоматологічної порцеляни.

\section{Таблиця 1 .}

Вміст вихідних компонентів в побутових і стоматологічних масах

\begin{tabular}{|l|c|c|}
\hline $\begin{array}{c}\text { Вихідний } \\
\text { компонент }\end{array}$ & $\begin{array}{c}\text { Побутова } \\
\text { порцеляна } \\
\text { (тверда), \% }\end{array}$ & $\begin{array}{c}\text { Стоматологічні } \\
\text { маси, \% }\end{array}$ \\
\hline Польовий шпат & $10 \div 25$ & $50 \div 81$ \\
\hline Кварц & $14 \div 35$ & $15 \div 30$ \\
\hline Каолін & $35 \div 70$ & $0 \div 4$ \\
\hline Пігменти & 1 & менше 1 \\
\hline
\end{tabular}

За фізичними властивостями порцеляна близька до стекол, іiї структура є анізотропною. При температурі $1100 \div 1300{ }^{\circ} \mathrm{C}$ калієвий шпат перетворюється в калієве польовошпатове скло. В розплаві каолін і кварц, що мають більш високі температури плавлення, також взаємодіють зі склом. При цьому, каолін утворює голковидні кристали муліту, що пронизують всю масу порцеляни. Висока в'язкість польовошпатового скла ускладнює видалення газових пухирців із порцелянового матеріалу, чим і обумовлює утворення закритих пор.

Мікроскопічними дослідженнями встановлено такі типові структурні елементи порцеляни:

- скловидна ізотропна маса, що складається 3 польовошпатового скла 3 різним ступенем насичення $\left(\mathrm{Al}_{2} \mathrm{O}_{3}\right.$ та $\left.\mathrm{SiO}_{2}\right)$;

- нерозчинні в склі оплавлені частки кварцу;

- кристали муліту $3 \mathrm{Al}_{2} \mathrm{O}_{3} \cdot 2 \mathrm{SiO}_{2}$, що розподілені в розплаві скла;

- пори.

Сучасна стоматологічна порцеляна за температурою випалу класифікується на декілька груп: тугоплавка (1300 - $\left.1370{ }^{\circ} \mathrm{C}\right)$, що використовується для виготовлення зубів або знімних протезів, середньо$\left(1090\right.$ - $\left.1260^{\circ} \mathrm{C}\right)$ та низькоплавка $\left(870-1065^{\circ} \mathrm{C}\right)$, що використовуються для виготовлення коронок, вкладок і мостовидних протезів.

Міцність порцеляни залежить від рецептури порцелянової маси та технології виробництва, що визначається за ISO 9693 «Стоматологічна металокераміка для зубного протезування». У відповідності до цих вимог, міцність на вигин у порцеляни повинна бути не менше 50 МПа. Так у сучасної порцеля- ни $E X-3$ Норитаkи (Норітакі, Японія») вона складає 100 - 110 МПа.

Проте опір зносу та фізико-механічні показники таких протезів, у ряді випадків не задовольняють вимогам стандартів до дентальних імплантатів, що відчувають значно більші механічні навантаження. Це не дозволяє використовувати їх для виготовлення суцільних стоматологічних зубів. В цьому випадку з успіхом застосовуються оксидна чи композиційна кераміка.

2. Полікристалічна оксидна кераміка.

Оксид алюмінію. Високощільна високочиста кераміка на основі $\alpha-\mathrm{Al}_{2} \mathrm{O}_{3}$ була першим керамічним матеріалом, що широко використовується в медицині. Він був уведений в клінічну ортопедію наприкінці 1960-х років (Boutin, France, Griss, Germany) i використовувався для виготовлення протезів головки шийки стегна і для виготовлення зубних імплантатів завдяки його винятковій корозійній стійкості, біосумісності, низького опору тертя, високого спротиву зносу і високій міцності $[4,5]$.

Висока твердість і тугоплавкість оксиду алюмінію ускладнюють технологічний процес виробництва індивідуальних конструкцій в стоматології. Поряд 3 цим, руйнування головок $3 \mathrm{Al}_{2} \mathrm{O}_{3}$ - кераміки обумовлене іiі недостатньою міцністю на згинання. Це привело до розвитку робіт зі створення протезів для стоматології на основі діоксиду цирконію.

Діоксид цирконію $\left(\mathrm{ZrO}_{2}\right)$ за міцністю, оптичними та механічними властивостями переважає інші керамічні стоматологічні матеріали. Так, $\mathrm{ZrO}_{2}$ характеризується унікальним комплексом властивостей: хімічною стабільністю, високою тріщиностійкістю, твердістю і світлопроникністю. Тому діоксид цирконію займає провідну роль у стоматологічному протезуванні [4, 5].

Діоксид цирконію розрахований на застосування в умовах високого навантаження та відрізняється високим опором напруження втомного руйнування, що $\epsilon$ винятково важливим при створенні стоматологічних матеріалів, які експлуатуються в умовах значних повторно-перемінних навантажень. Діоксид цирконію для стоматології зазвичай представляє тетрагональний полікристалічний оксид цирконію стабілізований оксидом ітрію, що відноситься до трансформаційно-зміцнених матеріалів. За відсутності високого вмісту моноклінної модифікації $\mathrm{ZrO}_{2}$, міцність при вигині $\mathrm{ZrO}_{2}$ в кілька разів вище, ніж у $\mathrm{Al}_{2} \mathrm{O}_{3}$, що робить його найбільш міцним матеріалом з відомих монолітних керамічних матеріалів.

Високі міцністні характеристики ускладнюють виготовлення суцільно-керамічних протезів із діоксиду цирконію, так як матеріал важко підлягає обробці навіть алмазними фрезами. Тільки 3 появою 
цифрових комп'ютерних технологій, а саме CAD/ CAM систем (Computer Aided Desing / Computer Aided Manufacture), кераміка на основі діоксиду цирконію набула широкого застосування. Дана технологія включає вибір вихідних даних із використанням цифрового об'ємного сканування зони протезування, створення тримірної моделі протезу 3 наступним виготовленням на станку-автоматі майбутнього протезу. За необхідності випал проводять, за визначеним виробником матеріалу, режимом термічного оброблення. Найбільш сучасні технології, наприклад CEREC, дозволяють проводити протезування за один сеанс у лікаря. Коронки на основі діоксиду цирконію ICE Zircon 3 керамічним облицюванням мають високу світлопроникаючу здатність та посилену міцність; використовуються в місцях 3 підвищеним жувальним навантаженням. Коронки на основі діоксиду цирконію Prettau Zircon за технологією Prettau з частковим облицюванням керамікою використовуються за призначенням лікаря - ортопеда $[6,7]$.

Однак, внаслідок низькотемпературної деградації (НТД) тетрагонального діоксиду цирконію при температурі $100-300{ }^{\circ} \mathrm{C}$ виникають проблеми щодо довгострокової стабільності та зношування кераміки на основі $\mathrm{ZrO}_{2}$. Пошукове дослідження матеріалів із стабілізованого ітрієм тетрагонального $\mathrm{ZrO}_{2}$ показало, що 20 - 30 \% тетрагональної фази перетворилося в моноклінну фазу через 3 - 6 років після імплантації [5]. Це перетворення супроводжується погіршенням шорсткості поверхні, зростанням зерен і мікророзтріскуванням, призводячи до підвищеного зносу і можливої передчасної відмови. Тому серед матеріалів для ортопедії діоксид цирконію біомедичного класу викликає найбільшу полеміку між вченими, виробниками і хірургами через ефект «старіння» (гідротермальної нестабільності), як результату впливу навколишнього середовища на фізико-технічні властивості кераміки. Також синтез керамічних матеріалів $\epsilon$ енергоємним процесом, що суттєво підвищує вартість виробів. Рішенням цієї проблеми є створення склокомпозиційних матеріалів, що відрізняються високими експлуатаційними властивостями, технологічністю та є менш вартісними у порівнянні з керамічними протезами.

3. Склокомпозиційні матеріали.

На сьогоднішній день переважна більшість незнімних естетичних протезів твердих тканин зубів $\mathrm{i}$ зубних рядів, що виготовляються у світі, є комбінованими та поєднують у собі металевий каркас і керамічне облицювання. Одночасне забезпечення високого модуля пружності металевих сплавів та міцності покриттів при розробленні металокерамічних мостовидних протезів дозволяє зняти обмеження за довжиною протезу та забезпечити їх відповідні екс- плуатаційні властивості під дією функціональних навантажень.

Польовошпатова склокераміка, яка зміцнена лейцитом. Лейцитвмісна стоматологічна склокераміка $є$ одним $з$ найбільш перспективних матеріалів при виготовленні металокерамічних коронок при протезуванні передніх та жувальних зубів. Завдяки високим механічним властивостям (міцність на згин 50 - 210 МПа), даний матеріал може бути використаний при пошаровому спіканні як грунтовий та опаковий шари, та, у разі забезпечення прозорості, як емалевий шар. Головна відмінність склокераміки від польовошпатного і лантанового скла, які тривалий час застосовуються для облицювання металокерамічних протезів, полягає у тому, що формування ситалізованої структури склокераміки з наявністю кристалів лейциту розміром до 1 мкм рівномірно розподілених в об'ємі, дозволяє забезпечити високі міцністні характеристики матеріалів, що є запорукою тривалого використання протезів. У той час, як міцність при вигині польовошпатової кераміки для облицювання металокерамічних протезів становить від 30 до 40 МПа, міцність подібного матеріалу, зміцненого лейцитом, наближається до 120 МПа. Лейцитові склокерамічні матеріали відрізняються високими естетичними властивостями [8].

Також ефективного застосування набули композиційні склокристалічні покриття, що успішно використовуються у зубопротезуванні, зокрема ситалове покриття «Сімет». Воно має лейцит-альбітовий склад та призначене для облицювання каркасів суцільнолитих зубних протезів, виготовлених зі стоматологічних сплавів металів та лейцит-гідроксиапатит-флюоритові покриття для стоматології та медичних виробів [8].

Склокераміка на основі слюди з добавкою фторидів. Склокерамічні матеріали на основі слюди 3 додаванням фторидів є продуктами складу $\mathrm{SiO}_{2}$, $\mathrm{K}_{2} \mathrm{O}, \mathrm{MgO}, \mathrm{Al}_{2} \mathrm{O}_{3}, \mathrm{ZrO}_{2}$ з добавкою фторидів деяких металів для надання зубним протезам флюорисцентних властивостей, аналогічних натуральним зубам. Для матеріалів цього складу процес ситалізації призводить до утворення центрів кристалізації і росту тетрасилікатних кристалів слюди всередині скломатриці. Як і в склокераміці на основі дисилікату літію, кристали слюди мають голчасту форму і блокують розвиток тріщин всередині матеріалу. Міцність при вигині цього матеріалу складає від 120 до 150 МПа, що в поєднанні з адгезією до твердих тканин зуба, є цілком достатньою для виготовлення коронок жувальних зубів, але недостатньою для виготовлення суцільнокерамічних мостовидних протезів.

Склокераміка на основі дисилікату літію. На сьогоднішній день склокераміка на основі дисиліка- 
ту літію вже тривалий час успішно застосовується у стоматології через іiї високу міцність, природний зовнішній вигляд та можливість пресування дуже тонких конструкцій. Міцність на вигин такої конкурентоспроможної високоякісної стоматологічної склокераміки складає 450 МПа. Широкого використання набули матеріали та покриття відомих іноземних виробників: «Degu Dent», «Ivoklar Vivadent AG», «Vita Zahnfabrik H. Rauter GmbH \& Co. KG», «SHOFU Inc.», «Noritake» та ін. Інноваційна склокераміка на основі дисилікату літію $\left(\mathrm{LS}_{2}\right)$ IPS e.max Press характеризується точністю, функціональністю та естетикою при одночасно високій міцності в 400 МПа [9]. Однак склокерамічні матеріали на основі дисилікату літію імпортного виробництва $\epsilon$ вартісними, що ускладнює процес розв'язання нагальних проблем протезування в Україні.

Метою роботи є обгрунтування перспективності використання вітчизняної літійсилікатної склокераміки для стоматологічного протезування.

\section{Матеріали та методи дослідження}

Для визначення можливості використання природної сировини при одержанні біоматеріалів було проведено гамма-спектрометричне дослідження за допомогою сцинтиляційного гамма-спектрометра СЕГ-001 «АКП-С». Діапазон вимірюваних енергій гамма-випромінювань якого складає від 50 до 3000 кеВ.

Критерієм радіаційної оцінки керамічних матеріалів та сировини для їх виробництва $є$ ефективна питома активність природних радіонуклідів (ЕРН), що здійснює $\gamma$-випромінювання матеріалів. Величина ефективної питомої активності ЕПА $\left(\mathrm{C}_{\mathrm{e}}\right.$. $)$ визначається як сума діючих активностей радію-226 $\left(\mathrm{C}_{\mathrm{Ra}}\right)$, торію-232 $\left(\mathrm{C}_{\mathrm{Th}}\right)$ та калію-40 $\left(\mathrm{C}_{\mathrm{K}}\right)$ за формулою

$$
C_{\text {eq. }}=C_{\mathrm{Ra}}+1,31 C_{\mathrm{Th}}+0,085 C_{\mathrm{K}}, \text { Бк· } \kappa^{-1},
$$

де 1,31 і 0,085 - відповідно, коефіцієнти для торія-232 та калія-40 за відношенням до радію-226.

Вид та кількість кристалічної фази в скломатеріалах визначали методами рентгенофазового (дифрактометр ДРОН-3М) та петрографічного (оптичний мікроскоп NU-2E) аналізів.

Експлуатаційні властивості літійсилікатної кераміки визначали за ISO 6872:2015 «Стоматологія. Керамічні матеріали».

Методологічний підхід до розв'язання поставленої задачі полягає у поетапному розробленні скломатриці - основи склокераміки, дослідженні кристалізаційної здатності стекол, виборі режимів термічної обробки, наступному синтезі базового скла та формуванні ситалізованої структури в процесі низькотемпературної короткотривалої терміч- ної обробки та визначенні відповідності технологічних та експлуатаційних властивостей одержаного матеріалу заданим вимогам.

Для синтезу скломатриці було обрано склади літійсилікатних стекол 3 вмістом оксидів, в мас. \%: $\mathrm{SiO}_{2} 50,0$ - 71,8; $\mathrm{Li}_{2} \mathrm{O} 11,0$ - 20,0; $\mathrm{Al}_{2} \mathrm{O}_{3} 0,1$ - 5,0; $\mathrm{K}_{2} \mathrm{O} 0,1$ - 2,0; $\mathrm{Na}_{2} \mathrm{O} 0,1$ - 10,5; $\mathrm{SrO} 0,1$ - 4,0; $\mathrm{CaO} 0,1$ - 3,5; $\mathrm{MgO} 0,1$ - 4,0; $\mathrm{ZnO} 0,1$ - 4,0; $\mathrm{ZrO}_{2}$ 0,1 - 11,0; $\mathrm{TiO}_{2}$ 0,1 - 5,0; $\mathrm{CeO}_{2} 0,1$ - 2,0; $\mathrm{LiF} 0,1$ - 3,5; $\mathrm{CaF}_{2} 0,1$ - 2,5; $\mathrm{P}_{2} \mathrm{O}_{5} 0,1$ - 4,0; $\mathrm{B}_{2} \mathrm{O}_{3} 0,1-6,0 ; \mathrm{La}_{2} \mathrm{O}_{3} 0,1-4,0 ; \mathrm{Sb}_{2} \mathrm{O}_{3} 0,1-1,5$ та $\mathrm{MnO}_{2} 0,1-4,0$.

Для синтезу фторапатитового покриття обрано біосумісні кальційфосфатосилікатні стекла 3 наступним оксидним складом (в мас \%): $\mathrm{SiO}_{2} 42,50$ - 50,03; $\mathrm{CaO} 9,38$ - 16,26; $\mathrm{P}_{2} \mathrm{O}_{5} 5,62$ - 9,74; $\mathrm{CaF}_{2}$ 1,44 - 6,28; $\mathrm{Na}_{2} \mathrm{O} 7,16$ - 8,42; $\mathrm{K}_{2} \mathrm{O} 6,80$ - 8,01; $\mathrm{Li}_{2} \mathrm{O}$ 1,02 - 4,53; $\mathrm{ZnO} 1,02$ - 4,53; $\mathrm{B}_{2} \mathrm{O}_{3} 5,47$ - 6,45; $\mathrm{Al}_{2} \mathrm{O}_{3}$ 7,23 - 8,51 та $\mathrm{MoO}_{3} 0,10$ - 0,50.

При складанні шихт для варки стекол використовували природні сировинні матеріали, технічні продукти та реактиви класифікації «х. ч.». Як сировинні матеріали були використані: калієва польовошпатова сировина (КПШС) Майдан-Вільського родовища (збагачений пегматит); пісок кварцовий; крейда; глинозем; борна кислота; циркон; карбонати літію та магнію; оксиди цинку, мангану, церію, титану, стронцію, лантану, молібдену та стібаю; амоній фосфорнокислий; фториди кальцію й літію.

Дослідженнями радіаційних властивостей КПШС і техногенної сировини встановлена належність абсолютної більшості цих матеріалів до 1 класу радіаційної безпеки $\left(\mathrm{C}_{\text {еф }} \leq 370\right.$ Бк·кГ $\left.{ }^{-1}\right)$, що свідчить про можливість їх використання як сировини при виготовленні керамічних виробів широкого вжитку.

Варку стекол здійснювали у корундових тиглях в лабораторній електричній печі впродовж 6 годин: літійсилікатні стекла - при температурі 1350 - $1400{ }^{\circ} \mathrm{C}$ та виливали в підігріті графітові форми з наступним повільним охолодженням, а кальційфосфатосилікатні - при температурі 1250 - $1300{ }^{\circ} \mathrm{C}$ з подальшим швидким охолодженням на металевій пластині. За даними рентгенофазового та петрографічного досліджень, після варки, у літійсилікатних стеклах спостерігалася відсутність кристалічної фази, а у кальційфосфатосилікатних - наявність кристалів гідроксиапатиту та фторапатиту в загальній кількості 15 - 20 об. \%, з розміром кристалів близько 1 мкм.

Скляні циліндричні заготовки на основі літійсилікатного скла попередньо витримують на стадії зародкоутворення при температурі $600-650{ }^{\circ} \mathrm{C}$ впродовж 30 - 60 хвилин. Процес формування виробів за технологією високотемпературного пресування складається 3: нагрівання заготовки від температу- 
ри $700{ }^{\circ} \mathrm{C}$ до температури розм'якшення скломатеріалу $\left(850-900{ }^{\circ} \mathrm{C}\right)$, заповнення скломасою гіпсової форми 3 подальшою короткотривалою витримкою (18 - 20 хв.) та повільного охолодження. Після високотемпературного пресування склокерамічний протез характеризується об'ємною тонкодисперсною кристалізацією з наявністю високоміцної кристалічної фази - дисилікату літію у кількості 40 - 60 об. \%. Після високотемпературного пресування протези покриваються фторапатитовим склокерамічним покриттям, виготовленим на основі подрібненого кальційфосфатосилікатного скла і пігментів, та випалюються при температурі $800-850{ }^{\circ} \mathrm{C}$, впродовж 1,0 - 1,5 хвилин [10].

\section{Результати та їх обговорення}

Порівняльна оцінка розроблених склокерамічних протезів для стоматології 3 маркуванням DL st.glass (розробник ХНУМГ ім. О.М. Бекетова) та існуючих склокерамічних протезів на основі дисилікату літію IPS e.max Press або фторапатиту IPS e.max ZirPress (розробник Ivoclar Vivadent) (табл. 2) дозволила встановити, що вітчизняні склокерамічні протези відрізняються вищими показниками в'язкості руйнування та модуля пружності, що дозволить підвищити їх експлуатаційну живучість при механічних навантаженнях (надмірні точкові навантаження). Експлуатаційні властивості розроблених склокерамічних протезів за ISO 6872:2015 знаходяться на рівні показників світових аналогів. Це дозволить їм успішно конкурувати на ринку України з відомими зарубіжними аналогами та сприяти забезпеченню соціальних пріоритетів держави у напрямку охорони здоров'я. Реалізація розробки у виробництві дозволить одержати вітчизняні склокерамічні протези для заміни зубів при суттєвому зниженні собівартості продукції.

Таблиця 2.

\section{Висновки}

Проаналізовані основні види керамічних матеріалів, які застосовуються для створення керамічних протезів зубів. Встановлено перспективність створення склокерамічних протезів для стоматології на основі дисилікату літію. Розроблено склади та технологічні параметри синтезу склокерамічних матеріалів на основі дисилікату літію за технологією високотемпературного пресування. Досліджено їх експлуатаційні властивості та проведено порівняльний аналіз зі світовими аналогами.

Впровадження результатів роботи дозволить вітчизняним стоматологічним клінікам відмовитись від вартісних закордонних аналогів. Соціальноекономічний ефект від впровадження розроблених стоматологічних матеріалів та покриттів полягає у зниженні витрат на лікування за рахунок скорочення майже втричі вартості протезу.

\section{References}

1. J.R. Kelly, P. Benetti Ceramic materials in dentistry: historical evolution and current practice Australian Dental Journal 2011; 56:(1 Suppl): 84 - 96 doi: 10.1111/j.1834-7819.2010.01299.x

2. Bajraktarova-Valjakova, E., Korunoska-Stevkovska, V., Kapusevska, B., Gigovski, N., BajraktarovaMisevska, C. and Grozdanov, A. Contemporary dental ceramic materials, a review: chemical composition, physical and mechanical properties, indications for use.Open Access Maced J. Med. Sci. - 2018. - 6(9). P. 1742 - 1755.

3. Ivoclar Vivadent: Інструкція з використання. URL: https://www.ivoclarvivadent.ua/\#I (дата звернення 15.02.2021).

4. Українські імплантати. Bauer's Implants. URL: https://dante.com.ua/uk/implantaciya-zubiv-suchasnij-

Властивості розроблених та зарубіжних склокерамічних протезів для стоматології

\begin{tabular}{|l|c|c|c|}
\hline \multicolumn{2}{|c|}{ Властивості } & \multicolumn{3}{c|}{ Маркування } \\
\cline { 2 - 4 } & DL st.glass & IPS e.max Press & IPS e.max ZirPress \\
\hline ТКЛР $\alpha_{\left(100-500^{\circ} \mathrm{C}\right)} \cdot 10^{-6}, \mathrm{~K}^{-1}$ & $90-100$ & 105 & 99 \\
\hline Міцність на згин (двовісний) $(\sigma)$, МПа & $400-450$ & 400 & 110 \\
\hline Модуль пружності (Е), ГПа & $100-110$ & 95 & 110 \\
\hline Коефіцієнт інтенсивності напруг $\left(\mathrm{K}_{1 \mathrm{c}}\right)$, МПа·м ${ }^{1 / 2}$ & $3,0-8,0$ & 2,75 & - \\
\hline Твердість за Віккерсом $(\mathrm{HV})$, ГПа & $5,4-6,0$ & 5,8 & 5,4 \\
\hline Хімічна стійкість, мкг/см ${ }^{2}$ & $35-40$ & 40 & 30 \\
\hline Температура термічної обробки та пресування $(\mathrm{T}),{ }^{\circ} \mathrm{C}$ & $850-900$ & $915-920$ & $900-910$ \\
\hline
\end{tabular}


diyevij-metod/ukrainskie-implanty-bauers-implantsua/ (дата звернення 13.01.2021).

5. Kelly, JR., Benetti, P. Ceramic materials in dentistry: historical evolution and current practice. - Aust Dent J. - 2011. - 56:(1 Suppl). - P. 84 - 96.

6. Саввова, О.В., Бабіч, О.В., Фесенко, О.І., Воронов, Г.К. Сучасні технології біосумісних матеріалів для кісткового ендопротезування : монографія. Харків : НТУ «ХПІ». - 2017. - 280 c.

7. Зиновенко, О.Г., Шинкевич, В.М., Садовская, И.В. Эстетическое протезирование с применением диоксида циркония. - Современная стоматология. 2014. - № 2. - С. 58 - 60.

8. Михайлина, Н.А., Подзорова, Л.И., Румянцева, Н.М., Шворнева, Л.И., Овчинникова, О.А., Анисимова,
С.В., Лебеденко, А.И., Лебеденко, И.Ю., Хван, В.И. Керамика на основе тетрагонального диоксида циркония для реставрационной стоматологии. Перспективные материалы. - 2010. - 3. - С. 44 - 48.

9. Керамические и стеклокристаллические материалы для стоматологии. - Успехи современного естествознания. $-2007 .-11$. - С. $70-72$.

10. Lithium silicate materials: Pat. $8,444,756$ B2 US: Int. Cl.: C03C 10/04, C03C 3/083, C09K 3/00. № 3/175,370; Filed 01.07.2011; Date of Patent. 01.10. 2013. - 5 p. 11. Комплексне біоактивне кальцій фосфатне склокристалічне покриття: Пат. 118712 Україна: МПК6 C03C 8/20, C03C 8/02, C03C 8/04, A61L 27/10. № a 201703096; заявл. 03.04.2017; опубл. 25.02.2019, Бюл. № 4. - 7 с. 